\title{
Keratin 8 expression in head and neck epithelia Christoph Matthias ${ }^{1}$, Brigitte Mack ${ }^{2}$, Alexander Berghaus ${ }^{2}$ and Olivier Gires $* 2,3$
}

\begin{abstract}
Address: ${ }^{1}$ Department of Otorhinolaryngology, Head and Neck Surgery, University of Goettingen Medical School, Robert-Kochstr. 40,37075 Göttingen, Germany, ${ }^{2}$ Department of Otorhinolaryngology, Head and Neck Surgery, Grosshadern Medical Center, Ludwig-MaximiliansUniversity of Munich, Marchioninistr. 15, 81377 Munich, Germany and ${ }^{3}$ Clinical Cooperation Group Molecular Oncology, Helmholtz-Zentrum München, German Research Center for Environmental Health, and Head and Neck Research Dept. Ludwig-Maximilians-University of Munich, Germany
\end{abstract}

Email: Christoph Matthias - christoph.matthias@medizin.uni-goettingen.de; Brigitte Mack - bmack@med.uni-muenchen.de; Alexander Berghaus - alexander.berghaus@med.uni-muenchen.de; Olivier Gires* - olivier.gires@med.uni-muenchen.de

* Corresponding author

Published: 22 September 2008

BMC Cancer 2008, 8:267 doi:10.1 |86/|47|-2407-8-267
Received: 4 June 2008

Accepted: 22 September 2008

This article is available from: http://www.biomedcentral.com//47/-2407/8/267

(c) 2008 Matthias et al; licensee BioMed Central Ltd.

This is an Open Access article distributed under the terms of the Creative Commons Attribution License (http://creativecommons.org/licenses/by/2.0), which permits unrestricted use, distribution, and reproduction in any medium, provided the original work is properly cited.

\begin{abstract}
Background: The intermediate filament forming protein keratin 8 (K8) is a tumour-associated antigen, which was shown to be over-expressed in a variety of malignancies. Here, we present a study of K8 expression in squamous epithelia of the head and neck area, including normal mucosa, hyperplastic and dysplastic leukoplakia, carcinomas of different sub-localisations, and lymph node metastases.
\end{abstract}

Methods: K8 expression was assessed upon immunohistochemistry with specific antibodies in cryosections of primary tumours of the head and neck area.

Results: K8 expression was characteristic of transformed tissue and marked early stages of disease, i.e. dysplastic oral leukoplakia, but not normal or hyperplastic epithelium. With the exception of carcinomas of the larynx and the tongue, K8 expression also strictly differentiated carcinomas from normal epithelium of the same origin. Furthermore, K8high was characteristic of cells, which had detached from the sites of primary tumours and had been invading the surrounding tissue at the time point of surgery.

Conclusion: $\mathrm{K} 8$ is an excellent marker for head and neck malignancies, which allows for early detection as well as for visualisation of potentially disseminating tumour cells in vivo.

\section{Background}

Cytokeratin 8 (K8) is a structural protein, which forms intermediate filaments within the cytoplasm of simple epithelial cells [1] as a dimer with CK18 [2]. Along with other keratins, K8/CK18 generate a stabilizing framework, which is cell shape determining and allows cells to cope with mechanical stress. Cytokeratin filaments further on represent a mesh of "paths" on which signalling mole- cules, metabolites, and pathogens can travel the cell in an orientated fashion. The regulation of the localization of K8 within cells and polymerization into intermediate filaments is dependent upon its phosphorylation. Two main kinase families are instrumental in this context: the MAP kinase family member $\mathrm{p} 38$ [3] and PKC- $\varepsilon$ related kinase [4]. Phosphorylation of K8 at serine in position $73\left(\mathrm{Ser}^{73}\right)$ is mediated by p38 under stress such as orthovanadate 
treatment, and regulates keratin organization [5]. High p38 kinase activity correlated with the formation of keratin granules, while low p38 activity, ergo low K8 Ser ${ }^{73}$ phosphorylation, was associated with a prevented disassembly of the filament network [5]. As a potential counter-regulator and eventually in order to balance the phosphorylation status of $\mathrm{K} 8$, the catalytic subunit of protein phosphatase 2A (PP2A) associates with and dephosphorylates K8 after hyposmotic stress [6]. However, dephosphorylation was site-specific and concerned Ser ${ }^{431}$, not Ser ${ }^{73}$. Additionally, K8 and CK18 hyperphosphorylation is a valuable marker for the progression of liver diseases such as non-cirrhotic hepatitis $\mathrm{C}$ infection or cirrhosis [7]. Disease associated mutations of K8 were reported for the case of cryptogenic liver diseases with single point mutations leading to the exchange of glycine at position 61 to a cysteine residue and of tyrosine $e^{53}$ to a histidine $[8,9]$. Gly ${ }^{61} \rightarrow$ Cys mutation was of major importance as it diminished the capacity of cells to reorganize keratin filament. Recently, Ku and colleagues reported on an animal model for the Gly61 $\rightarrow$ Cys mutation. In transgenic mice, this point mutant of $\mathrm{K} 8$ predisposed animals to liver injury along with a decreased Ser73 phosphorylation [10]. When ectopically expressed at the plasma membrane of carcinoma cells [11], K8 serves as a tissue-type plasminogen activator (tPA) [12-15] and might help tumour cells to remodel or invade surrounding tissue [16].

Generally speaking, K8 is believed to be involved in the process of carcinogenesis [17-21] and silencing of it resulted in sensitization for cisplatin [22]. We have isolated $\mathrm{K} 8$ as a tumour-associated antigen, which elicits a humoral response in vivo in patients suffering from carcinomas of the head and neck area [23]. A continuative study on the profile of K8-specific autoantibodies in healthy donors and patients revealed that autoantibody titers allowed to differentiate normal and diseased persons, but not to discriminate between cases of benign and malignant disease [24]. Normal squamous epithelium, which represents the great majority of epithelia of the head and neck and of malignancies thereof, is devoid of K8. De novo expression of K8 was observed for head and neck carcinomas, however in a small patients cohort [25]. Studies including larger numbers of patients with head and neck malignancies are to the best of our knowledge missing so far and therefore the topic of the present investigation.

Here, we present a comprehensive survey of K8 expression in normal mucosa, leukoplakia, head and neck squamous cell carcinomas (HNSCC), and lymph node metastases of the head and neck area. We have used immunohistochemistry on cryosections for this purpose as it allows thorough detection of $\mathrm{K} 8$ and, importantly, the assign- ment of staining to particular cell types within samples as opposed to RT-PCR or immunoblotting. K8 positivity was a hallmark of transformed epithelia where it correlated with early stages of carcinogenesis in dysplastic leukoplakia. K8 was also strongly over-expressed in the majority of HNSCC tested. Importantly, K8 $8^{\text {high }}$ was a characteristic of disseminated tumour cells and in overt lymph node metastases. For this reason, K8 represents a valuable marker for head and neck malignancies in early stages of the disease and of invasive growth of tumour cells.

\section{Methods}

\section{Tissue samples}

All human samples were obtained after informed consent according to the Helsinki Declaration and on the basis of an approval by the local ethical committee (Ethikkommision der Medizinischen Fakultät der Ludwig-MaximiliansUniversität München; file reference $N^{\circ}$ 087/03). Fiftyseven samples of normal mucosa were obtained from patients suffering from chronic tonsillitis $(n=9)$, tonsilar carcinomas $(\mathrm{n}=10)$, laryngeal carcinomas $(\mathrm{n}=9)$, oropharyngeal carcinomas $(n=6)$, hypopharyngeal carcinomas $(n=4)$, carcinomas of the tongue $(n=7)$, mouth $(n=4)$, valeculla $(n=2)$, vocal cords $(n=2)$, nasopharynx $(\mathrm{n}=1)$, alveolar ridge $(\mathrm{n}=1)$, uvula $(\mathrm{n}=1)$, and nasal concha hyperplasia $(n=1)$. Nineteen samples of oral leukoplakia, six samples of lymph node metastases, and one hundred and two samples of head and neck carcinomas of different localisation were collected. All specimens had been confirmed by routine clinical diagnosis according to the UICC TNM classification of 2003 for head and neck carcinomas [26] and histopathologic examination by two expert pathologists. Characteristics used for the diagnosis were tumour size $(\mathrm{T})$, locoregional lymph node status $(\mathrm{N})$, and the presence of distant metastases at the time of first diagnosis $(\mathrm{M})$. Tissue specimen were shock-frozen in liquid nitrogen and embedded in tissue-tek (Sakura, Fintek, NL) to generate $4 \mu \mathrm{m}$ non-consecutive sections.

\section{Immunohistochemistry}

The mouse anti-human K8 clone $35 \beta \mathrm{H} 11$ primary antibody was used (Dako, Glostrup, DK), (diluted 1:100). Immunostaining was performed using the avidin-biotinperoxidase complex method (Vectastain, Vector laboratories, Burlingame, CA, USA) according to the manufacturer's protocol. Briefly, after fixation in acetone $(10 \mathrm{~min})$, endogenous peroxidase activity was inhibited upon treatment with $0.03 \% \mathrm{H} 2 \mathrm{O} 2 / \mathrm{PBS}$ (10 min). Before specific staining, unspecific antigenic sites were blocked with normal goat serum or normal horse serum. Sections were then incubated with the respective primary antibody for 1 hour at room temperature (RT) followed by incubation with biotinylated anti-rabbit or anti-mouse immunoglobulins and then with avidin-biotin-peroxidase complex (30 minutes at RT for each step). After each step, sections were 
washed with PBS. Specific peroxidase activity was visualized with $0.05 \%$ 3-amino-9-ethylcarbazol as a substrate (Sigma, Deisenhofen, Germany) and 0.02\% H2O2/0,1 M Na-acetat buffer pH5.5). Counterstaining was performed with Mayers hematoxylin. Control staining was performed in the absence of primary antibody. Immunostained sections were evaluated upon light microscopy by two independent investigators. Double immunostainings were performed with a monoclonal anti Ki67 antibody (Dako, Glostrup, DK) using the avidin-biotin-peroxidase method (ABC, red-brown staining), together with the K8specific $35 \beta \mathrm{H} 11$ antibody using alkaline phosphataseanti-alkaline phosphatase method and fast Blue BB salt (Sigma, Deisenhofen, Germany) as a chromogenic substrate (deep blue staining). Negative controls were conducted in the absence of primary antibodies for every detection system. Sample evaluation was performed by two experienced researchers (BM and $\mathrm{OG}$ ) according to criteria of staining intensities $(0-+++)$ published elsewhere [25].

\section{Results}

\section{K8 expression in head and neck epithelia}

In a first step, we studied the expression pattern of $\mathrm{K} 8$ in a small subset of tissues including normal epithelium of the oropharynx, oral leukoplakia, and hypopharynx carcinomas. Appraisal of tissue integrity was performed after hematoxilin staining, while diagnosis was conducted beforehand by two expert pathologists according to UICC's TNM classification. Evaluation of K8 expression was subdivided into negative, weak, intermediate, and strong as was described in Gires et al. [25]. K8 was not detected in normal mucosa except for a very mild and incidental expression in cells of the stratum basale (Figure 1A). In a hypopharynx carcinoma specimen, both microscopically normal mucosa and malignant cells were adjacent. K8 staining allowed for a strict differentiation of both tissues with carcinoma cells expressing high levels of K8 while normal mucosa retained its typical staining pattern restricted to some cells of the stratum basale (Figure 1B). Staining of additional leukoplakia specimens demonstrated that $\mathrm{K} 8$ de novo expression is a fairly early event in cell transformation, which starts in cells of the basal membrane layer. In case regular epithelial stratification was lost and cells of the basal membrane layer proliferated to generate multiple layers, K8 expression was strongest in these cells and progressed to suprabasal cells (Figure $1 \mathrm{C})$. Where incipient transformation was detected, this aberrant K8 synthesis could even be restricted to nests of cells which proliferated, protruded in the surrounding tissue, and lay in areas characterized by massive cellular infiltrates (Figure 1D and data not shown). In hypopharynx carcinomas the expression of K8 was almost in 100\% of tumour cells and mostly strong (Figure 1E), and posi- tively correlated with the marker of proliferation Ki67 (Figure 1F).

\section{K8 expression in diverse head and neck malignancies}

Since increased or even de novo expression of K8 was characteristic of transformation in a small cohort of patients (data herein and Gires et al. 2006), we next studied K8 in a larger collective of patients. Firstly, microscopically normal mucosas $(\mathrm{n}=57)$ were assessed. Tissue specimens originated from the oropharynx and larynx of patients suffering from either chronic tonsillitis, tonsillar carcinomas, laryngeal carcinomas, oropharyngeal carcinomas, hypopharyngeal carcinomas, tongue carcinomas, buccal carcinomas, carcinomas of the valeculla, vocal cords, nasopharynx, alveolar ridge, uvula, or from nasal concha hyperplasia. Cryosections were stained with hematoxillin in order to appreciate tissue integrity and non-transformed phenotypes. The second parameter was considered as a second appraisal following routine diagnosis by pathologists. Except for four oropharyngeal mucosas from tonsillar carcinoma $(\mathrm{n}=1)$, oropharyngeal carcinomas $(\mathrm{n}$ $=2$ ), and carcinoma of the valeculla $(n=1), 100 \%$ of oropharyngeal normal mucosas were devoid of K8 (Table $1)$. In all four divergent cases, K8 was expressed to intermediate $(++)$ or strong $(+++)$ levels in varying percentages of tumour cells included in the specimens. In sharp contrast, two laryngeal normal mucosas were strongly $(+++)$ positive in $100 \%$ of cells (Table 1 ). In summary, normal oropharyngeal but not laryngeal mucosa was to $100 \%$ devoid of $\mathrm{K} 8$.

Secondly, oral leukoplakia ( $\mathrm{n}=19$ ), which in some cases represented pre-malignant lesions, were stained with K8 specific antibodies. In normal or hyperplastic leukoplakia $(n=9) 7$ tissue specimens were negative for K8 (78\%) and 2 specimens expressed K8 weakly in 10\% and to intermediate levels in $5 \%$ of the cells, respectively (Table 2 ). Four out of six (66.7\%) dysplastic leukoplakia expressed K8 to intermediate $(++)$ or even strong $(+++)$ levels in varying percentages of cells. Four leukoplakia samples actually represented carcinomas of small sizes (T1-2) and all expressed K8 to strong (+++) levels (Table 2).

Six lymph node metastases (LNM) from primary carcinomas of different origin expressed $\mathrm{K} 8$ to intermediate or strong levels and with a percentage range of positive cells from $5-100 \%$ (Table 3 ). Interestingly, three out of six LNM displayed a strong (+++) K8 expression in $100 \%$ of cells.

In a last step, we assessed the expression of K8 in carcinomas $(\mathrm{n}=102)$ of various localizations including hypopharynx $(n=10)$, oro-hypopharynx $(n=2)$, larynx $(\mathrm{n}=23)$, oropharynx $(\mathrm{n}=13)$, larynx-hypopharynx $(\mathrm{n}=$ $2)$, vocal cords $(n=2)$, mouth $(n=6)$, tonsil $(n=15)$, 
A

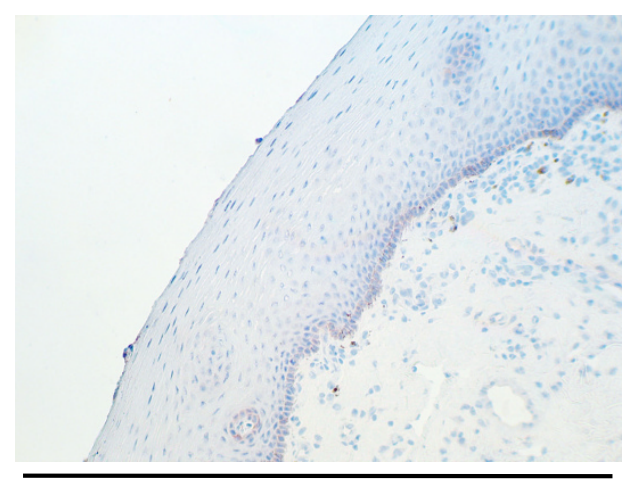

normal mucosa

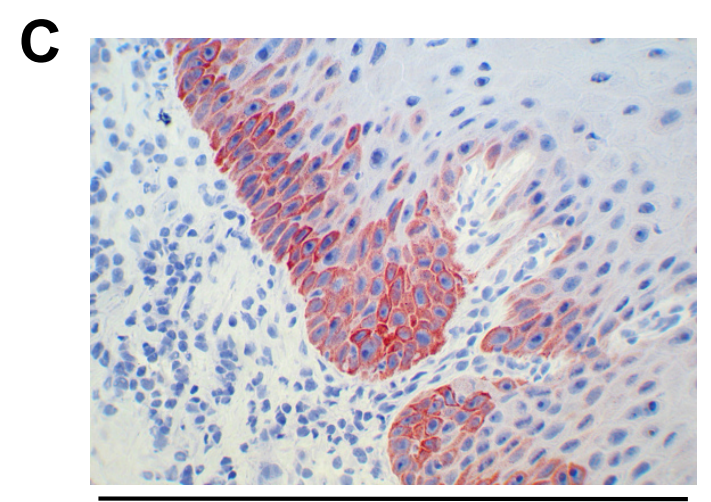

leukoplakia

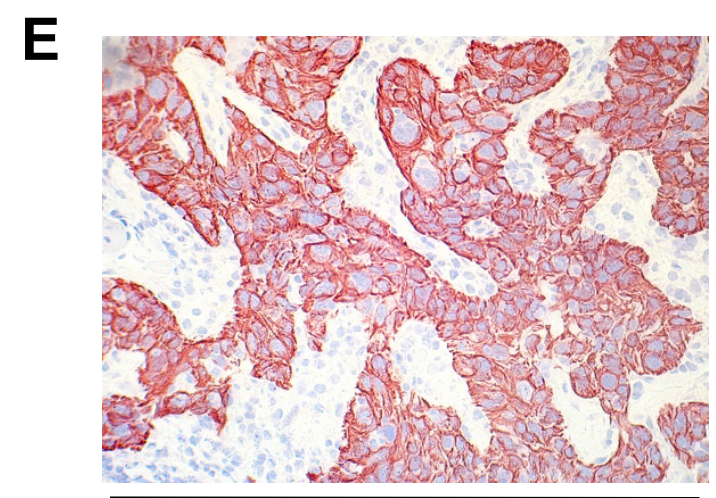

hypopharynx CA
B

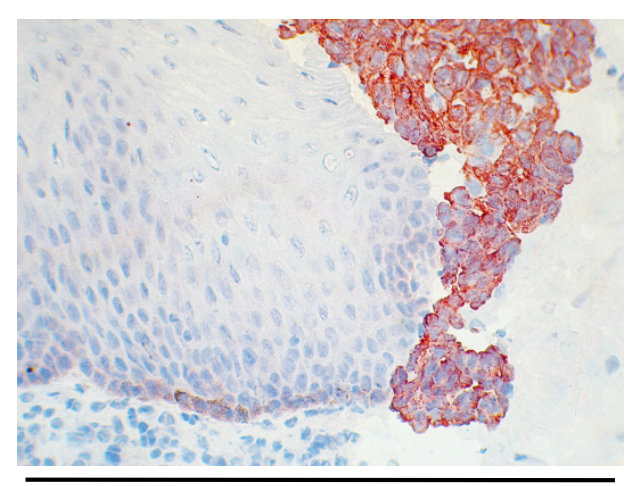

normal mucosa/CA

D

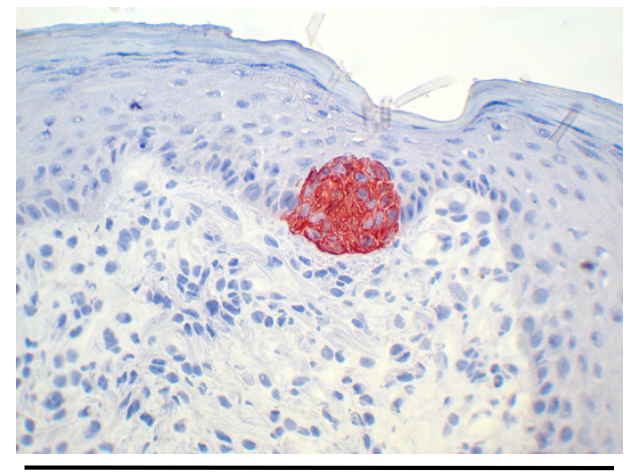

leukoplakia

$\mathbf{F}$

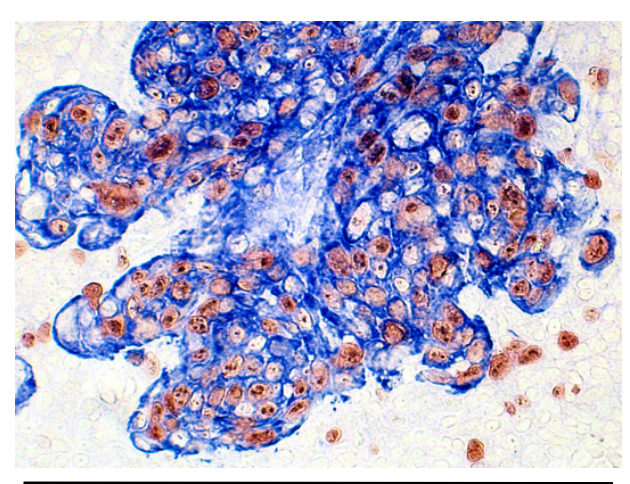

hypopharynx CA

(CK8 vs. Ki67)

\section{Figure I}

K8 expression pattern in head and neck epithelia. $\mathrm{K} 8$ was visualised by immunohistochemistry with specific antibodies in normal mucosa (A), hypopharynx carcinoma with adjacent normal mucosa (B), oral leukoplakia (C, D), hypopharynx carcinoma (E, F). Ki67 was stained in parallel to detect proliferating cells (F). Colour coding is indicated below figure IF. 
Table I: K8 expression in normal mucosa.

\begin{tabular}{|c|c|c|c|}
\hline PATIENT & K8 INTENSITY & \% OF TISSUE & LOCALISATION OF MUCOSA \\
\hline chron. Tonsillitis & - & I & oropharynx \\
\hline chron. Tonsillitis & - & l & oropharynx \\
\hline chron. Tonsillitis & - & l & oropharynx \\
\hline chron. Tonsillitis & - & I & oropharynx \\
\hline chron. Tonsillitis & - & l & oropharynx \\
\hline chron. Tonsillitis & - & l & oropharynx \\
\hline chron. Tonsillitis & - & l & oropharynx \\
\hline chron. Laryngitis & - & l & oropharynx \\
\hline chron. Tonsillitis & - & 1 & oropharynx \\
\hline Ton $\mathrm{Ca}$ & +++ & 80 & oropharynx * \\
\hline Ton $\mathrm{Ca}$ & - & 1 & oropharynx \\
\hline Ton Ca & - & l & oropharynx \\
\hline Ton $\mathrm{Ca}$ & - & l & oropharynx \\
\hline Ton $\mathrm{Ca}$ & - & l & oropharynx \\
\hline Ton Ca & - & I & oropharynx \\
\hline Ton $\mathrm{Ca}$ & - & l & oropharynx \\
\hline Ton $\mathrm{Ca}$ & - & l & oropharynx \\
\hline Ton Ca & - & l & oropharynx \\
\hline Ton $\mathrm{Ca}$ & - & l & oropharynx \\
\hline Larynx Ca & - & l & oropharynx \\
\hline Larynx neoplasia & - & l & oropharynx \\
\hline Larynx Ca & - & l & oropharynx \\
\hline Larynx Ca & - & l & oropharynx \\
\hline Larynx Ca & - & l & oropharynx \\
\hline Larynx Ca & - & I & oropharynx \\
\hline Larynx Ca & - & 1 & oropharynx \\
\hline Larynx Ca & +++ & 100 & larynx \\
\hline Larynx Ca & +++ & 100 & larynx \\
\hline Oropharynx Ca & - & l & oropharynx \\
\hline Oro-Hypopharynx $\mathrm{Ca}$ & +++ & 20 & oropharynx * \\
\hline Oropharynx Ca & - & 1 & oropharynx \\
\hline Oropharynx Ca & - & l & oropharynx \\
\hline Oropharynx Ca & - & 1 & oropharynx \\
\hline Oropharynx Ca & +++ & 40 & oropharynx * \\
\hline Hypopharynx $\mathrm{Ca}$ & - & 1 & oropharynx \\
\hline Hypopharynx $\mathrm{Ca}$ & - & l & oropharynx \\
\hline Hypopharynx Ca & - & I & oropharynx \\
\hline Larynx-Hypopharynx Ca & - & l & oropharynx \\
\hline Tongue $\mathrm{Ca}$ & - & l & oropharynx \\
\hline Tongue $\mathrm{Ca}$ & - & l & oropharynx \\
\hline Tongue $\mathrm{Ca}$ & - & l & oropharynx \\
\hline Tongue $\mathrm{Ca}$ & - & l & oropharynx \\
\hline Tongue $\mathrm{Ca}$ & - & l & oropharynx \\
\hline Tongue $\mathrm{Ca}$ & - & l & oropharynx \\
\hline Tongue $\mathrm{Ca}$ & - & l & oropharynx \\
\hline Mouth $\mathrm{Ca}$ & - & l & oropharynx \\
\hline Mouth $\mathrm{Ca}$ & - & I & oropharynx \\
\hline Mouth $\mathrm{Ca}$ & - & l & oropharynx \\
\hline Mouth $\mathrm{Ca}$ & - & 1 & oropharynx \\
\hline Vallecula Ca & ++ & 20 & oropharynx * \\
\hline Vallecula Ca & - & l & oropharynx \\
\hline Vocal cords $\mathrm{Ca}$ & - & l & oropharynx \\
\hline Vocal cords Ca & - & I & oropharynx \\
\hline Nasopharynx Ca & - & l & oropharynx \\
\hline Alveolar ridge $\mathrm{Ca}$ & - & l & oropharynx \\
\hline Uvula $\mathrm{Ca}$ & - & l & oropharynx \\
\hline Nasal concha hyperplasia & - & I & nasal epithelium \\
\hline
\end{tabular}

Given are the intensity of $\mathrm{K} 8$ expression, diagnostic findings, percentages of positive cells within affected tissues, and localisation of the healthy mucosa.

-: no staining; +: weak; ++: intermediate, +++: strong. Chron. Tonsillitis: chronic tonsillitis; Ton Ca: tonsillar carcinoma.

*: CK8-positive cells represented either dysplatic or carcinoma cells within samples assessed. 
valecula $(\mathrm{n}=13)$, and tongue $(\mathrm{n}=16)$. Evaluation of $\mathrm{K} 8$ intensities in these malignancies demonstrated that intermediate and especially strong K8 expression was characteristic of head and neck carcinomas, independently of the sub-localization (Figure 2A). Negative or weak K8 expression accounted only for maximally $37.5 \%$ as seen for tongue carcinomas and was generally below 20\% (mean value $11.65 \% \pm 12$ ). Oppositely, intermediate and strong K8 staining was seen in $62.5 \%$ to $100 \%$ of all cases (Figure 2B; mean value $88.25 \% \pm 11.5$ ).

\section{K8 expression in disseminated and tumour cells and metastases}

Staining of various carcinoma samples with hematoxillin/ eosin revealed the presence of tumour cells that had detached from the primary tumour into surrounding tissue at the time point of surgery. These disseminated tumour cells (DTCs) were in the close proximity of the bulk of carcinoma cells and were present either as single cells or as small nests composed of up to 15-30 cells. Immunohistochemical staining of these samples with antibodies specific for K8 strongly marked detached cells. Interestingly, K8 expression in DTCs was often superior to cells of the primary tumour suggesting a need for single cells to overexpress K8 (Figure 3). Noteworthy, detached and $\mathrm{K} 8$ positive cells were commonly not seen within densely packed infiltrates of immune cells but rather in loosened areas of the tissue specimens. In accordance with those findings, K8 positive cells with the highest expression levels often came to localize at the edge of tissue protruding into the submucosa, eventually generating a remarkable lining of $\mathrm{K} 8^{\text {high }}$ cells, i.e. cells displaying strong K8 expression (Figure 4A). Since K8 ${ }^{\text {high }}$ was a hallmark of detached carcinoma cells, we next analyzed its pattern in lymph node metastases of tonsillar carcinomas. Again $\mathrm{K} 8^{\text {high }}$ was strictly confined to islets of metastatic tumour cells (Figure 4B).

\section{Discussion}

Reliable markers for pre-malignant lesions retained their paramount importance, as they are believed to bring about significant improvements of patients' care and overall survival [27]. This notion was best exemplified by the use of prostate-specific antigen PSA for the early diagnosis of prostate carcinoma [28]. Clearly, the earlier a malignancy of the head and neck area is diagnosed, the better the prognosis for the patient [29]. Hence, detection of premalignant lesions is highly desirable as is the visualization of disseminated tumour cells, which are to be seen as founders of metastases [30-32]. With these prerequisites in mind it is interesting to retrieve from the present stuy that K8 (i) is absent in normal mucosa composed of squamous epithelium and in contrast to adenomatous epithelium, that (ii) K8 expression differentiates dysplastic lesions, carcinomas in situ, and small established carcinomas (i.e. T1-2) from normal tissue and hyperplastic lesions within oral leukoplakia, and finally that (iii) K8 thoroughly marks single detached tumour cells. These features and the de novo expression of qualify K8 as a worth candidate for the early detection of pre-malignant lesions, which might progress to overt malignancies with significantly enhanced probability [33], and for disseminated

Table 2: K8 expression in oral leukoplakia.

\begin{tabular}{|c|c|c|c|}
\hline LP & K8 INTENSITY & \% OF TISSUE & DIAGNOSTIC FINDINGS \\
\hline $\mathbf{I}$ & - & l & normal \\
\hline 9 & - & l & normal \\
\hline II & - & l & normal \\
\hline 5 & - & l & hyperplasia \\
\hline 6 & - & l & hyperplasia \\
\hline 7 & - & 1 & hyperplasia \\
\hline 4 & - & 1 & hyperplasia \\
\hline 14 & + & 10 & hyperplasia \\
\hline 19 & ++ & 5 & hyperplasia \\
\hline 2 & - & I & dysplasia (weak) \\
\hline 12 & - & 1 & dysplasia \\
\hline 8 & ++ & 10 & dysplasia \\
\hline 10 & +++ & 90 & dysplasia \\
\hline 13 & ++ & 5 & dysplasia \\
\hline 18 & +++ & 10 & dysplasia \\
\hline 17 & +++ & 10 & SCC, GI \\
\hline 15 & +++ & 20 & $\mathrm{~T} 2, \mathrm{~N} 0, \mathrm{Mx}, \mathrm{G} 3$ \\
\hline 16 & +++ & 20 & TI, Nx, Mx, GI \\
\hline 3 & +++ & 100 & TI, G2-3 \\
\hline
\end{tabular}

Given are the intensity of K8 expression, diagnostic findings accoding to TNM classification, and percentages of positive cells within affected tissues. -: no staining; +: weak; ++: intermediate, +++: strong.

SCC: squamous cell carcinoma, no TNM status available; LP: leukoplakia. 
Table 3: K8 expression in lymph node metastases.

\begin{tabular}{lccc}
\hline LNM & K8 INTENSITY & \% OF TISSUE & TNM/G \\
\hline CUP & ++ & 5 & G2 \\
Soft palate Ca & ++ & 5 & T2/G2 \\
CUP & ++ & 70 & G3 \\
Adenocystic Ca & +++ & 100 & G3 \\
Tonsillar Ca & +++ & 100 & T2/G2 \\
Tongue Ca & +++ & 100 & T2/G2
\end{tabular}

Given are the intensity of $K 8$ expression, diagnostic findings of the cognate carcinoma accoding to TNM classification and grading $(G)$, and percentages of positive cells within affected tissues.

-: no staining; +: weak; ++: intermediate, +++: strong.

Ca: carcinoma, CUP: carcinoma of unknown primary.

tumour cells in head and neck carcinomas. Additionally, $\mathrm{K} 8$ was released as a circulating marker from apoptotic non-small cell lung carcinoma cells as a full-length and proteolytic cleavage-resistant protein and might hence represent a valuable biomarker for head and neck malignancies [34].

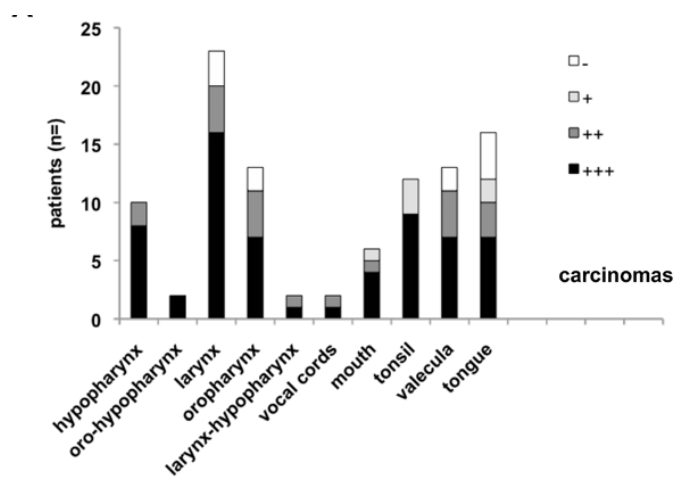

B

\begin{tabular}{lcccc}
\multicolumn{4}{c}{ tissue } & CK8 intensity \\
\hline & $-(\%)$ & $+(\%)$ & $++(\%)$ & $+++(\%)$ \\
\hline hypopharynx & 0 & 0 & 20 & 80 \\
oro-hypopharynx & 0 & 0 & 0 & 100 \\
larynx & 13 & 0 & 17 & 70 \\
oropharynx & 15 & 0 & 30 & 55 \\
larynx-hypopharynx & 0 & 0 & 50 & 50 \\
vocal cords & 0 & 0 & 50 & 50 \\
mouth & 0 & 16 & 16 & 67 \\
tonsil & 0 & 20 & 20 & 60 \\
valecula & 15 & 0 & 30 & 55 \\
tongue & 25 & 12.5 & 18.75 & 43.75
\end{tabular}

\section{Figure 2}

K8 expression in head and neck squamous cell carcinomas. (A) $\mathrm{K} 8$ was visualised by immunohistochemistry with specific antibodies in the indicated specimens of HNSCC, expression intensities are given as "no staining" (-), "weak staining" (+), "intermediate staining" (++), and "strong staining" (+++). (B) K8 staining intensities of tumour specimens are depicted as percentages of all specimens from one given origin.
From a mechanistic and molecular point of view, and with respect to the over-expression of $\mathrm{K} 8$ in cancer cells, two eventualities are to be envisaged. Firstly, disseminating and invading cells might require a reorganization of their cytoskeleton to improve motility and epithelial-tomesenchymal transition (EMT), which could be warranted by keratins of simple epithelia as is K8. Data from Chu and colleagues disclosed an ability of K8 and K18 to foster the invasive potential when ectopically expressed in murine L fibroblasts [16]. Along this line, assessment of p38 kinase activity in disseminated cells appears expedient. K8 Ser ${ }^{73}$ serves as a substrate for p38 kinase and phosphorylation at this position is crucial for the destabilization of intermediate filaments [3,5,35]. Reorganization, especially destabilization of intermediate filaments occurs under various physiological conditions such as mechanic stress, during epithelial cell homeostasis, exposure to chemicals (vanadate, ocadaic acid), and during mitosis. Common to all these processes is the recruitment of active p38 kinase to depolimerized keratin granules and phosphorylation of $\mathrm{K} 8$ at $\operatorname{Ser}^{73}[5,11]$. Hence, one may also envisage the simultaneous assessement of K8 expression and of $\operatorname{Ser}^{73}$ phosphorylation as an additional surrogate marker for the mitotic index. A second scenario must be considered, in which $\mathrm{K} 8$ serves as a receptor for plasminogen and $\mathrm{tPA}$ at the plasma membrane of tumour cells [12-14]. By doing so, K8 will enhance the proteolytic activity at the plasma membrane and facilitate tissue remodelling and invasion. Such an eventuality is supported by data presented herein. Single tumour cells that were already detached from the main tumour at the time of sample asservation displayed highest K8 expression, which may foster proteolytic activity and invasion. Regulatory processes involved in the de novo expression of $\mathrm{K} 8$ in these tumour cells are poorly understood. Recent work by Lacina et al. disclosed a potential for non-malignant stroma cells, i.e. tumourassociated fibroblasts, to induce K8 expression on normal keratinocytes in vitro $[36,37]$. Thus, the tumour microenvironment needs to be seen as a strong modulator of protein cell surface expression of carcinoma cells. Clearly, both eventualities, namely remodelling of cell structures and improvement of the proteolytic appartus of carcinoma cells, are not mutually exclusive but may even be both instrumental in parallel.

The findings presented in this study of K8 expression are in accordance with and complementing previous data that demonstrated de novo synthesis of $\mathrm{K} 8$ in dysplastic lesions as well as in head neck carcinomas. However, these former studies were conducted in substantially smaller cohorts and without differentiation of tumour sub-localizations $[25,38]$. Subdividing head and neck tissues according to their precise localization revealed minor differences in the K8 expression profile. Hypopharynx, oropharynx, larynx, 


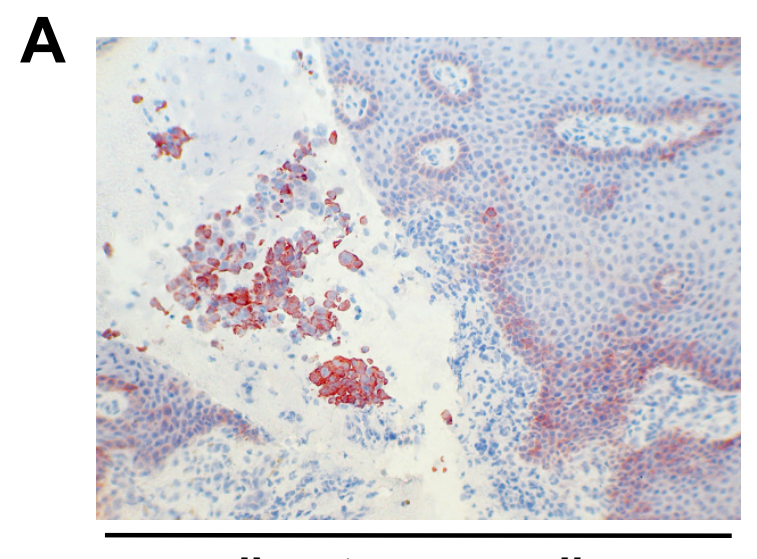

diss. tumour cells

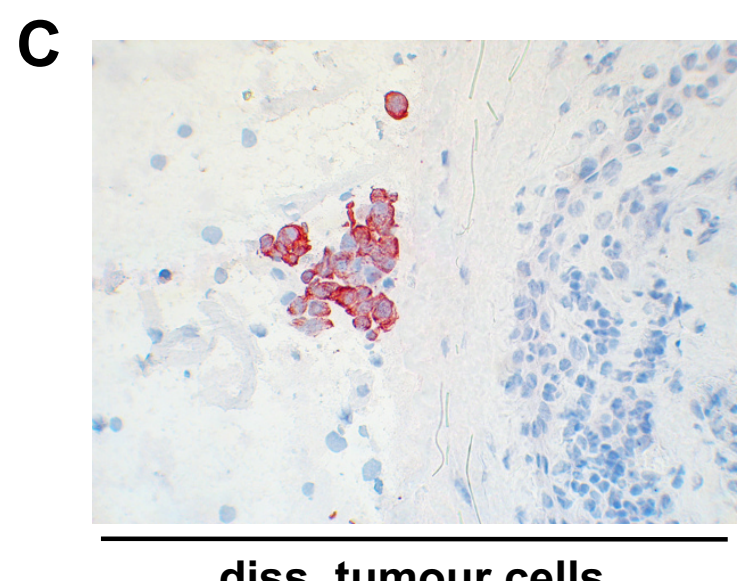

B

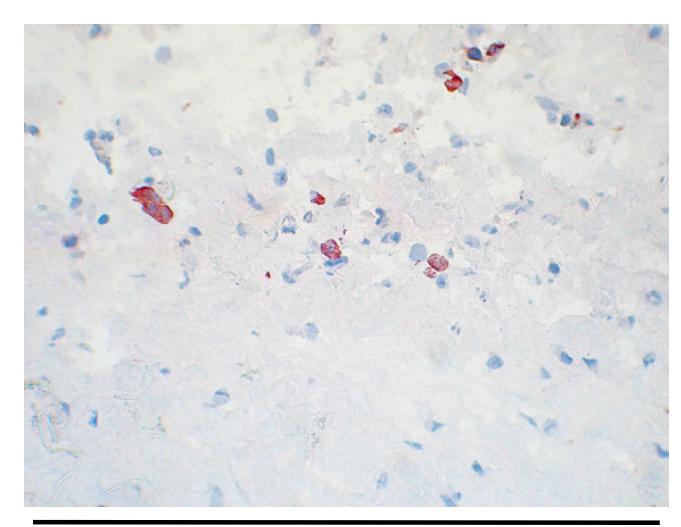

diss. tumour cells

D

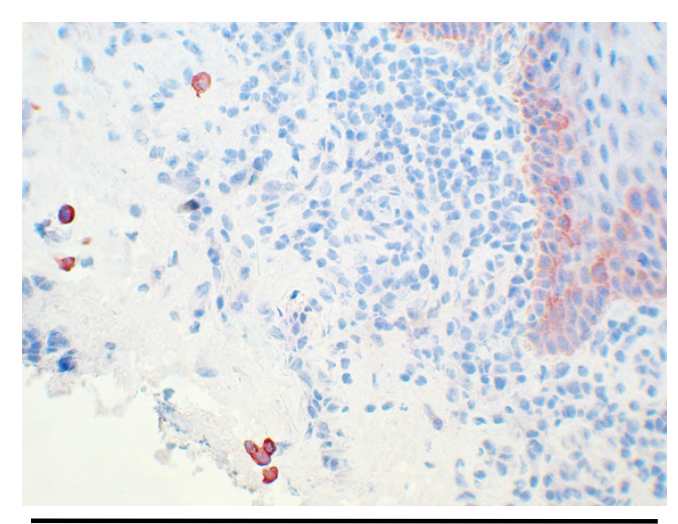

diss. tumour cells

Figure 3

$\mathbf{K} 8$ expression in detached tumour cells. $\mathrm{K} 8$ was visualised by immunohistochemistry with specific antibodies in head and neck carcinoma specimens. Depicted are tumours cells that had detached from the primary tumour at the time of surgery and occurred as single cells or small islets of tumour cells (less than 30 cells).

valecula, and vocal cords were characterized by $>85 \%$ of samples expressing intermediate to strong levels of K8. In contrast, carcinomas of the tongue were different since they displayed a more heterogeneous repartition with $37.5 \%$ of samples expressing no or weak levels of $\mathrm{K} 8$. Also, normal mucosa from the larynx was always positive for K8, pinpointing differences amongst healthy epithelia, too. Therefore, tongue and laryngeal carcinomas appear less amenable to a K8-based diagnosis.

Taken together our data qualify K8 as an excellent marker for head and neck carcinomas, lymph node metastases, and for tumour cells that have already detached from the primary tumour.

\section{Conclusion}

The intermediate filament protein $\mathrm{K} 8$ is known as a tumour-associated antigen. We present a survey of K8 expression in head and neck epithelia that demonstrates the specific staining of $\mathrm{K} 8$ in pre-malignant and malignant tissue versus normal cells. Dysplastic and tumour cells expressed K8 to strong levels, as did disseminated tumour cells. Hence, K8 is an excellent marker for the visualisation and diagnosis of pre-malignancies and DTCs in the head and neck area.

\section{Abbreviations}

K8: cytokeratin 8; K18: cytokeratin 18; DTC: disseminated tumour cell; HNSCC: head and neck squamous cell carci- 
A

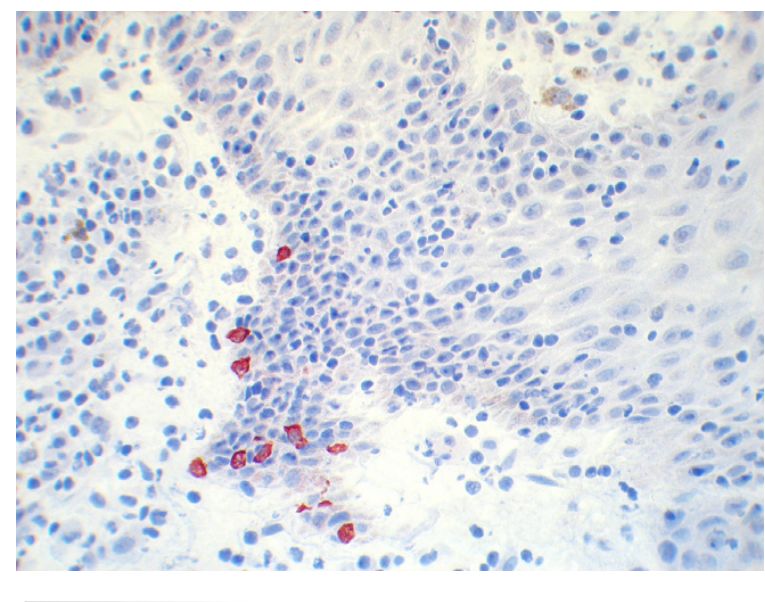

leukoplakia
B

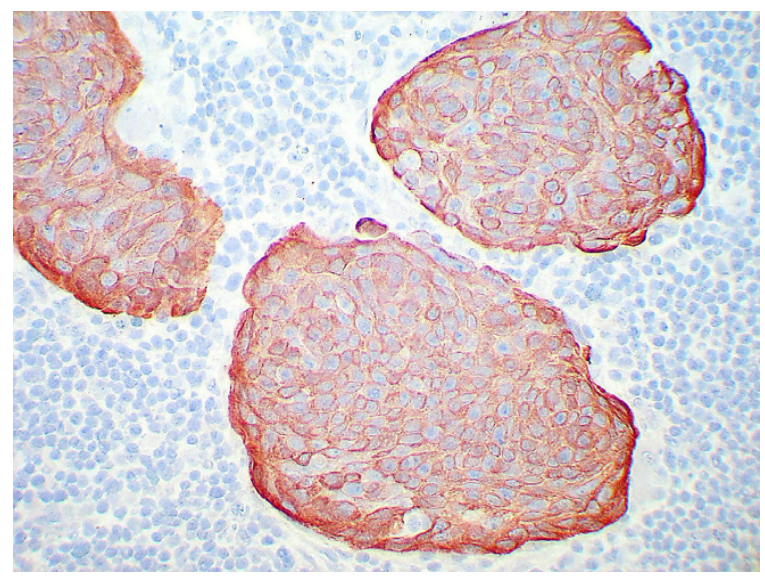

LNM (tonsillar CA)

\section{Figure 4}

K8 expression in leukoplakia and in lymph node metastases. $K 8$ was visualised by immunohistochemistry with specific antibodies at the protruding edge of dysplastic leukoplakia (left panel) and in lymph node metastases of a patient suffering from a tonsillar carcinoma (right panel).

noma; MAP kinase: mitogen-activated protein kinase; $P B S$ : phosphate balance salt solution; $P K C$ : protein kinase $C$; $R T$ : room temperature.

\section{Competing interests}

The authors declare that they have no competing interests.

\section{Authors' contributions}

$\mathrm{CM}$ and $\mathrm{AB}$ were in charge of patients' recruitment, sample assessments, and study design. BM performed all stainings shown in the manuscript. OG wrote the manuscript, analysed the acquired data, and was responsible for the study design together with CM. All authors read and approved the final manuscript.

\section{Acknowledgements}

Parts of the present work were supported by grants from the Deutsche Forschungsgemeinschaft to CM and OG (GI-540/I-I).

\section{References}

I. Leube RE, Bosch FX, Romano V, Zimbelmann R, Hofler H, Franke WW: Cytokeratin expression in simple epithelia. III. Detection of mRNAs encoding human cytokeratins nos. 8 and 18 in normal and tumor cells by hybridization with cDNA sequences in vitro and in situ. Differentiation 1986, 33(1):69-85.

2. Magin TM, Vijayaraj P, Leube RE: Structural and regulatory functions of keratins. Exp Cell Res 2007, 3 I 3(10):202I-2032.

3. Ku NO, Azhar S, Omary MB: Keratin 8 phosphorylation by p38 kinase regulates cellular keratin filament reorganization: modulation by a keratin I-like disease causing mutation. J Biol Chem 2002, 277( (13): 10775-10782.

4. Omary MB, Baxter GT, Chou CF, Riopel CL, Lin WY, Strulovici B: PKC epsilon-related kinase associates with and phosphorylates cytokeratin 8 and I8. J Cell Biol 1992, I I 7(3):583-593.
5. Woll S, Windoffer R, Leube RE: p38 MAPK-dependent shaping of the keratin cytoskeleton in cultured cells. J Cell Biol 2007, I77(5):795-807.

6. Tao GZ, Toivola DM, Zhou Q, Strnad P, Xu B, Michie SA, Omary MB: Protein phosphatase-2A associates with and dephosphorylates keratin 8 after hyposmotic stress in a site- and cellspecific manner. J Cell Sci 2006, I I 9(Pt 7): | 425- I 432.

7. Toivola DM, Ku NO, Resurreccion EZ, Nelson DR, Wright TL, Omary MB: Keratin 8 and 18 hyperphosphorylation is a marker of progression of human liver disease. Hepatology 2004, 40(2):459-466.

8. Ku NO, Gish R, Wright TL, Omary MB: Keratin 8 mutations in patients with cryptogenic liver disease. N Engl J Med 200I, 344(2I): I580-I 587.

9. Ku NO, Omary MB: Effect of mutation and phosphorylation of type I keratins on their caspase-mediated degradation. J Biol Chem 200I, 276(29):26792-26798.

10. Ku NO, Omary MB: A disease- and phosphorylation-related nonmechanical function for keratin 8. J Cell Biol 2006, 174(I): I I5-125.

II. Gires O, Andratschke M, Schmitt B, Mack B, Schaffrik M: Cytokeratin 8 associates with the external leaflet of plasma membranes in tumour cells. Biochem Biophys Res Commun 2005, 328(4): II54- II62.

12. Hembrough TA, Kralovich KR, Li L, Gonias SL: Cytokeratin 8 released by breast carcinoma cells in vitro binds plasminogen and tissue-type plasminogen activator and promotes plasminogen activation. Biochem J 1996, 31 7(Pt 3):763-769.

13. Hembrough TA, Li L, Gonias SL: Cell-surface cytokeratin 8 is the major plasminogen receptor on breast cancer cells and is required for the accelerated activation of cell-associated plasminogen by tissue-type plasminogen activator. J Biol Chem 1996, 27 I (4I):25684-2569I.

14. Hembrough TA, Vasudevan J, Allietta MM, Glass WF, Gonias SL: A cytokeratin 8-like protein with plasminogen-binding activity is present on the external surfaces of hepatocytes, HepG2 cells and breast carcinoma cell lines. J Cell Sci 1995, I08(Pt 3): I07I- 1082.

15. Kralovich KR, Li L, Hembrough TA, Webb DJ, Karns LR, Gonias SL: Characterization of the binding sites for plasminogen and 
tissue-type plasminogen activator in cytokeratin 8 and cytokeratin 18. J Protein Chem 1998, I7(8):845-854.

16. Chu YW, Runyan RB, Oshima RG, Hendrix MJ: Expression of complete keratin filaments in mouse $\mathbf{L}$ cells augments cell migration and invasion. Proc Natl Acad Sci USA 1993, 90(9):426I-4265.

17. Lam KY, Loke SL, Shen XC, Ma LT: Cytokeratin expression in non-neoplastic oesophageal epithelium and squamous cell carcinoma of the oesophagus. Virchows Arch 1995, 426(4):345-349.

18. Ikeda K, Tate G, Suzuki T, Mitsuya T: Coordinate expression of cytokeratin 8 and cytokeratin 17 immunohistochemical staining in cervical intraepithelial neoplasia and cervical squamous cell carcinoma: an immunohistochemical analysis and review of the literature. Gynecol Oncol 2008, I08(3):598-602.

19. Gharib TG, Chen G, Wang H, Huang CC, Prescott MS, Shedden K, Misek DE, Thomas DG, Giordano TJ, Taylor JM, et al.: Proteomic analysis of cytokeratin isoforms uncovers association with survival in lung adenocarcinoma. Neoplasia 2002, 4(5):440-448.

20. Cintorino M, Tripod SA, Santopietro R, Antonio P, Lutfi A, Chang F, Syrjanen S, Shen Q, Tosi P, Syrjanen K: Cytokeratin expression patterns as an indicator of tumour progression in oesophageal squamous cell carcinoma. Anticancer Res 200I, 2I(6A):4195-420I.

21. Raul U, Sawant S, Dange P, Kalraiya R, Ingle A, Vaidya M: Implications of cytokeratin 8/ 8 filament formation in stratified epithelial cells: induction of transformed phenotype. Int $J$ Cancer 2004, I II(5):662-668.

22. Wang Y, He QY, Tsao SW, Cheung YH, Wong A, Chiu JF: Cytokeratin 8 silencing in human nasopharyngeal carcinoma cells leads to cisplatin sensitization. Cancer Lett 2008.

23. Gires O, Munz M, Schaffrik M, Kieu C, Rauch J, Ahlemann M, Eberle D, Mack B, Wollenberg B, Lang S, et al.: Profile identification of disease-associated humoral antigens using AMIDA, a novel proteomics-based technology. Cell Mol Life Sci 2004, 6I(10): I I 98-1207.

24. Ahlemann M, Schmitt B, Stieber P, Gires O, Lang S, Zeidler R: Evaluation of CK8-specific autoantibodies in carcinomas of distinct localisations. Anticancer Res 2006, 26(I B):783-789.

25. Gires O, Mack B, Rauch J, Matthias C: CK8 correlates with malignancy in leukoplakia and carcinomas of the head and neck. Biochem Biophys Res Commun 2006, 343(I):252-259.

26. O'Sullivan B, Shah J: New TNM staging criteria for head and neck tumors. Semin Surg Oncol 2003, 2 I(I):30-42.

27. Misek DE, Patwa TH, Lubman DM, Simeone DM: Early detection and biomarkers in pancreatic cancer. J Natl Compr Canc Netw 2007, 5(10):|034-|04|.

28. Thompson IM, Ankerst DP: Prostate-specific antigen in the early detection of prostate cancer. Cmaj 2007, I 76(13): 1853-1858.

29. Lang S, Wollenberg B, Dellian M, Steuer-Vogt MK, Schwenzer K, Sautier W, Chucholowski M, Eckel R, Faas I, Wilmes E, et al.: [Clinical and epidemiological data of patients with malignomas of the head and neck]. Laryngorhinootologie 2002, 8 I (7):499-508.

30. Klein CA: The systemic progression of human cancer: a focus on the individual disseminated cancer cell - the unit of selection. Adv Cancer Res 2003, 89:35-67.

31. Schmidt-Kittler O, Ragg T, Daskalakis A, Granzow M, Ahr A, Blankenstein T], Kaufmann M, Diebold J, Arnholdt H, Muller P, et al.: From latent disseminated cells to overt metastasis: genetic analysis of systemic breast cancer progression. Proc Natl Acad Sci USA 2003, I00(13):7737-7742.

32. Schardt JA, Meyer M, Hartmann CH, Schubert F, Schmidt-Kittler O, Fuhrmann C, Polzer B, Petronio M, Eils R, Klein CA: Genomic analysis of single cytokeratin-positive cells from bone marrow reveals early mutational events in breast cancer. Cancer Cell 2005, 8(3):227-239.

33. Reichart PA, Philipsen HP: Oral erythroplakia - a review. Oral Oncol 2005, 4 I (6):55I-56I.

34. Ishii T, Bandoh S, Fujita J, Ohtsuki Y, Tojo Y, Kanaji N, Fukunaga $Y$, Ueda $Y$, Ishida T, Kubo A: Full-length cytokeratin 8 is released and circulates in patients with non-small cell lung cancer. Tumour Biol 2008, 29(1):57-62.

35. He T, Stepulak A, Holmstrom TH, Omary MB, Eriksson JE: The intermediate filament protein keratin 8 is a novel cytoplas- mic substrate for c-Jun N-terminal kinase. J Biol Chem 2002, 277(13): 10767-10774.

36. Lacina L, Dvorankova B, Smetana K Jr, Chovanec M, Plzak J, Tachezy R, Kideryova L, Kucerova L, Cada Z, Boucek J, et al.: Marker profiling of normal keratinocytes identifies the stroma from squamous cell carcinoma of the oral cavity as a modulatory microenvironment in co-culture. Int J Radiat Biol 2007, 83( I I12):837-848.

37. Lacina L, Smetana K Jr, Dvorankova B, Pytlik R, Kideryova L, Kucerova L, Plzakova Z, Stork J, Gabius HJ, Andre S: Stromal fibroblasts from basal cell carcinoma affect phenotype of normal keratinocytes. Br J Dermatol 2007, I 56(5):819-829.

38. Xu XC, Lee JS, Lippman SM, Ro JY, Hong WK, Lotan R: Increased expression of cytokeratins CK8 and CKI 9 is associated with head and neck carcinogenesis. Cancer Epidemiol Biomarkers Prev 1995, 4(8):87|-876.

\section{Pre-publication history}

The pre-publication history for this paper can be accessed here:

http://www.biomedcentral.com/1471-2407/8/267/pre pub
Publish with Bio Med Central and every scientist can read your work free of charge

"BioMed Central will be the most significant development for disseminating the results of biomedical research in our lifetime. "

Sir Paul Nurse, Cancer Research UK

Your research papers will be:

- available free of charge to the entire biomedical community

- peer reviewed and published immediately upon acceptance

- cited in PubMed and archived on PubMed Central

- yours - you keep the copyright 